\title{
CEPHALIC SPREAD OF NEUROBLASTOMAS IN CHILDREN
}

\author{
BY \\ W. I. B. ONUIGBO \\ From the Pathology Department, The University and Western Infirmary, Glasgow
}

(RECEIVED FOR PUBLICATION JANUARY 11, 1961)

The two classics on the tumours now known as neuroblastomas date back only to the beginning of this century. First, Pepper (1901) published 'A study of congenital sarcoma of the liver and adrenal'. One of his six cases was a girl of 9 months whose adrenal tumour had spread not only to the liver but also to the skull. Not long afterwards Hutchison (1907) discussed the cephalic spread of neuroblastomas in children.

In 1910 the University of Edinburgh accepted Frew's thesis that neuroblastomas usually metastasize ipsilaterally to the orbit and skull (Frew, 1911). Today, however, his conclusions still divide the profession. Thus, Duke-Elder (1952), among others, is of the view that the orbital metastasis 'appears first with remarkable regularity on the side corresponding to the affected adrenal', whereas Pack, Horning and Ariel (1952) maintain, as do others, that the site of the primary neuroblastoma 'could in no way be found attributable for the site or number of metastases', although Willis (1952) concedes that 'there is only a small modicum of truth in this hypothesis'.

The purpose of this paper, therefore, is to re-examine the available evidence and to evaluate the lateralization of cephalic metastases occurring in neuroblastomas.

\section{Investigation}

This paper analyses 132 neuroblastomas metastasizing to the orbit and skull in children. One hundred and one cases were collected from the literature, care being taken to exclude duplicated cases; 22 were obtained from the records of The Hospital for Sick Children, Great Ormond Street, London, and nine from the Royal Hospital for Sick Children, Yorkhill, Glasgow.

The origin of the primary tumour on the right or left side of the body was first ascertained. Next, it was noted whether the ipsilateral or contralateral orbit was involved, the criteria of involvement being combinations of exophthalmos, ecchymosis, strabismus, papilloedema, and para-orbital swellings. When the orbital deposits were bilateral, the side first involved was determined. If this was not expressly stated, then the side showing the grosser involvement was taken as that which was invaded earlier. Lastly, if orbital metastases were absent or inadequately described, then recourse was had to the skull in order to find out which side contained a secondary deposit or exhibited a greater amount of such deposits.

\section{Results}

The Table summarizes the topographical distribution of metastases in 132 adequately described cases of neuroblastoma. The trend towards ipsilateral invasion was manifest in 86 cases, while in 46 the trend was contralateral.

Instead of the chance of metastasis being equal between the ipsilateral and the contralateral orbit and skull, there seems to be a double chance of deposits being found ipsilaterally. The $\chi^{2}$ test of goodness of fit (between observed ipsilateral frequency and expected ipsilateral frequency of one half) may be applied. Following Fisher and Yates (1957), six classes are distinguished in the Table, the classes being grouped so as to ensure that the expected frequency is not less than 5 ; the summation is taken over all classes. Accordingly, $\chi^{2}=114 \cdot 223$ $-86=26 \cdot 223$. Since there are 5 degrees of freedom in the above six classes, this $\chi^{2}$ value is highly significant for the probability of this result being due to chance is 0.001 . We may conclude, therefore, that in all probability neuroblastomas spread preferentially to the orbit and skull on the same side.

\section{Discussion}

For the above conclusion to be valid, the series must be unbiased. First, there must be a faithful inclusion of all the adequately described cases which I came across. That the series is in all probability free from biased selection is attested to by the fact that as many as 101 cases have been collected from 
TABLE

TOPOGRAPHICAL DISTRIBUTION OF CEPHALIC METASTASES IN 132 NEUROBLASTOMAS, WITH CALCULATION OF $\chi^{2}$

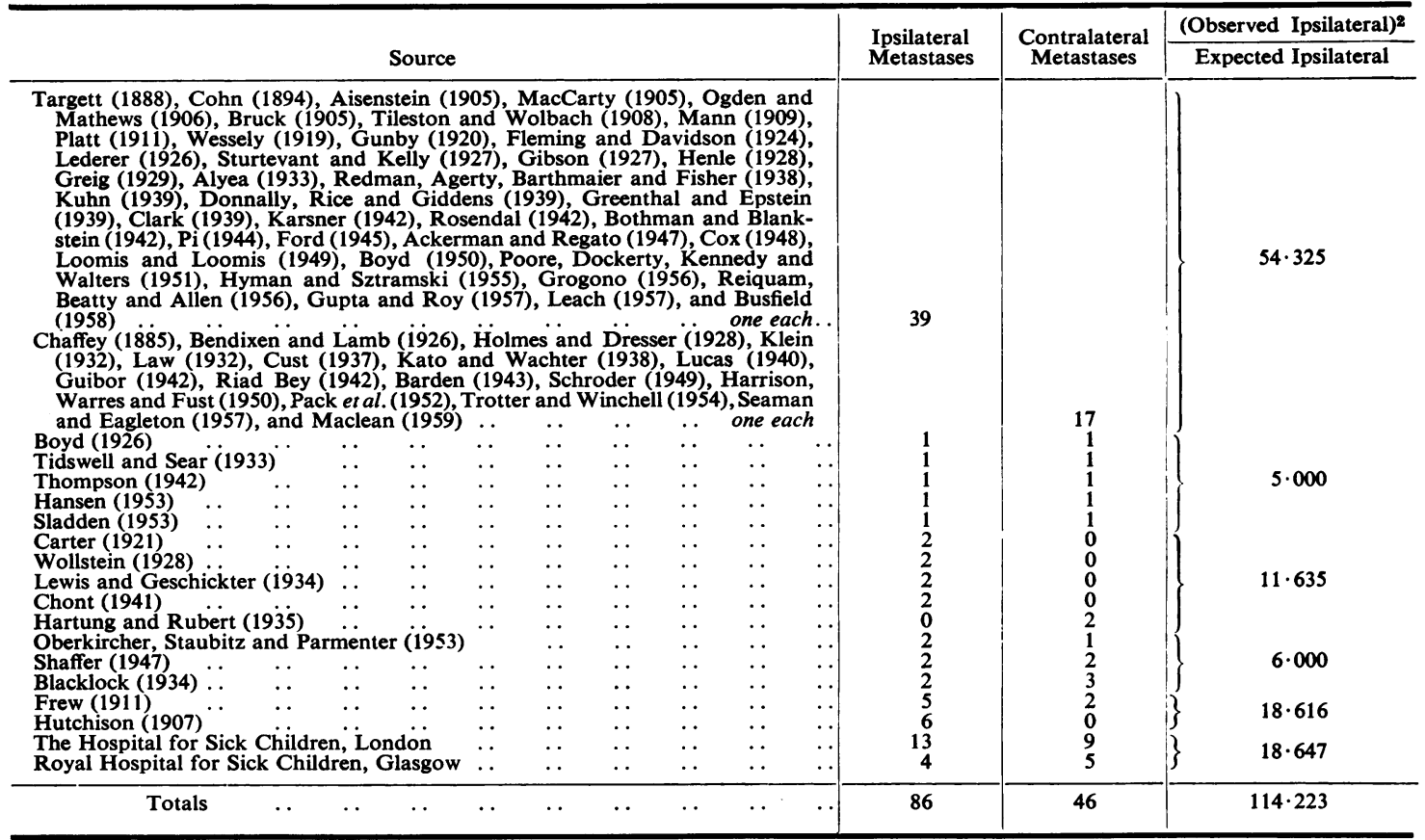

the literature; the estimated total of published cases is 450 (Pack et al., 1952) and about $20 \%$ spread cephalically (Stowens, 1959).

Another source of error was borne in mind. Poore (1949) made the sound suggestion that in interpreting figures collected from the literature the possibility must be considered that 'cases may be more likely to appear in the literature if they describe the "typical" syndromes, including the asymmetry advanced by Frew and widely quoted by others'. However, I am persuaded that at no time did Frew's hypothesis of asymmetry-preferential ipsilateral metastasis-enjoy such common acceptance that it influenced the type of case getting into print. Indeed, it seems to me that preconceptions do not appear to have inclined authors to record cases which harmonize with the view that they happen to hold. Thus, the case reported by Karsner (1942), who was opposed to Frew, exhibited initial ipsilateral invasion of the orbit; and, conversely, that reported by Cust (1937), who supported Frew, showed invasion of the contralateral orbit.

Perhaps, the issue of metastasis of neuroblastomas is still fogged because, as Steward (1958) pointed out, few doctors see enough cases to have a clear picture of the natural history of the disease. Hitherto, reports refuting or supporting Frew's concept of ipsilateral cephalic metastasis have been based upon only a few cases. In the present contribution, however, the accumulation of a large enough series has made statistical evaluation possible.

Frew was basically right, but he erred by overstating his case. Since he asserted that cephalic metastasis was ipsilateral 'in nearly every instance', every case which, thereafter, did not spread ipsilaterally was held to negative his hypothesis. To me, the position that should now be taken is that neuroblastomas metastasize preferentially to the ipsilateral orbit and skull to a statistically significant extent.

Clearly, arterial dissemination per se can hardly account for this pattern. Some authorities, notably Neale (1954) and Belt (1959), still agree with Frew that this pattern is suggestive of lymphogenous dissemination, but most others now indict the blood stream. In particular, ever since Batson (1940) brought the vertebral venous system into the limelight, opinion has veered in favour of metastasis by this route to the head. Thus, before Batson's epochal work, Boyd $(1926,1932)$ was satisfied that 
neuroblastomas spread by way of the lymphatics to the orbit, but, subsequently, Boyd (1958) has favoured venous dissemination.

Nevertheless, it is noteworthy that Batson (1942) himself contrasted lymph and venous blood flow and concluded that the flow within the vertebral venous system was such that 'no barrier exists at the midline'. If this is so, then a consistent ipsilateral localization of cephalic deposits should not be attributed to venous transportation. It seems, therefore, that lymphogenous metastasis should continue to receive our serious attention for, as I have argued elsewhere (Onuigbo, 1959), this mode of metastasis is in the main ipsilateral.

Hitherto, orthodox teaching, e.g. Cameron (1954), has been that 'blood invasion is indispensable if a tumour is to spread to distant parts'. Currently, however, research on the circulating cancer cell is revealing that up to $99 \%$ (Moore, Sandberg and Watne, 1959) of these cells apparently come to grief in the blood stream. The question ought to be posed and if possible answered by concerted efforts: What role does lymph play in transporting cancer cells to distant sites? We may be missing an important link in the chain of our knowledge of the mechanism of metastasis by largely ignoring lymphatic pathways. In particular, it is now a century since Virchow (1860) wrote concerning the 'very essential and important fact that the fibrin which circulates in lymph differs in certain respects from that contained in the blood'. Perhaps, such differences between blood and lymph may hold the key to our future advances in understanding cancer metastasis.

\section{Summary}

(1) Today, opinion is divided as to whether neuroblastomas show any tendency towards ipsilateral metastasis to the orbit and skull.

(2) A statistical study has, therefore, been made of the topographical distribution of the metastases in 132 neuroblastomas with cephalic involvement. One hundred and one cases were collected from the literature, 22 cases from The Hospital for Sick Children, Great Ormond Street, London, and nine from the Royal Hospital for Sick Children, Yorkhill, Glasgow.

(3) Eighty-six neuroblastomas exhibited an ipsilateral trend in their cephalic metastases, and only 46 displayed a contralateral trend. The difference in favour of ipsilateral metastasis is highly significant $\left(\chi^{2}=28 \cdot 223, p<0 \cdot 001\right)$.

(4) Ipsilateral preponderance of metastases is thought to be suggestive not of arterial or venous dissemination but of lymph-borne metastasis. Since current research suggests that very many of the circulating cancer cells apparently come to grief in the blood stream, there is need for concerted work on the fate of these cells in the lymph stream. It may well be that the role of the lymphatics in distant dispersal of cancer is underestimated.

I am grateful to my chief, Professor D. F. Cappell, to Dr. M. Bodian of The Hospital for Sick Children, Great Ormond Street, London, and Dr. A. M. Macdonald of the Royal Hospital for Sick Children, Glasgow, for the opportunity to carry out this survey.

\section{REFERENCES}

Ackerman, L. V. and Regato, J. A. del (1947). Cancer, p. 787. Mosby, St. Louis.

Aisenstein, S. M. (1905). Beiträge z. Kasuistik der Nebennierentumoren im Kindesalter. Inaug. Diss. Zürich, 1905. Quoted by Tileston, W. and Wolbach, J. B. (1908).

Alyea, E. P. (1933). Medulloblastoma involving the kidney. Sth. med. J. (Bgham, Ala.), 26, 753.

Barden, $R$. P. (1943). The similarity of clinical and roentgen findings in children with Ewing's sarcoma (endothelial myeloma) and sympathetic neuroblastoma. Amer. J. Roentgenol., 50, 575 .

Batson, O. V. (1940). The function of the vertebral veins and their rôle in the spread of metastases. Ann. Surg., 112, 138.

rôle in the spread of metastases. Ann. Surg., 112, 138 . Ann. intern. Med., 16, 38 .

Belt, E. (1959). In Cancer: Diagnosis and Treatment, ed. J. B. Field, p. 351. Churchill, London.

Bendixen, P. A. and Lamb, F. H. (1926). Malignant tumors of the adrenal in children with report of a case. J. Lab. clin. Med., $12,130$.

Blacklock, J. W. S. (1934). Neurogenic tumours of the sympathetic system in children. J. Path. Bact., 39, 27.

Bothman, L. and Blankstein, S. S. (1942). The eye in adrenal sympathicoblastoma (neuroblastoma). Importance of ocular findings, with first pathologic report of metastatic tumor in choroid. Arch. Ophthal. (Chicago), 27, 746.

Boyd, R. W. (1950). Adrenal neuroblastoma. Canad. med. Ass. J., 63,153 .

Boyd, W. (1926). Three tumors arising from neuroblasts. Arch. Surg. (Chicago), 12, 1031.

Surg. (Chicago), 12, 1031.
(1932). A Text-Book of Pathology: An Introduction to Medicine, p. 678. Kimpton, London.

(1958). Pathology for the Physician, 6th ed., p. 505. Kimpton, London.

Bruck, A. W. (1905). Ein Fall von kongenitalen Lebersarkom und Nebennierensarkom mit Metastasen. Jahrb. f. Kinderheilk., 62, 82. Quoted by Hutchinson, R. (1907).

Busfield, P. I. (1958). Neuroblastoma in orthopaedic practice. J. Bone Jt Surg., 40B, 47.

Cameron, G. R. (1954). The liver as a site and source of cancer. Brit. med. $J_{\text {., }} 1,347$.

Carter, W. E. (1921). Medullary malignancies of the suprarenal gland, with report of cases. Amer. J. Dis. Child., 22, 244.

Chaffey, W. C. (1885). Multiple sarcoma in a child. (Card specimen.) Trans. path. Soc. Lond., 36, 415.

Chont, L. K. (1941). Neuroblastoma and its roentgen diagnosis.

Report of eight cases. Amer. J. Roentgenol., 46, 809.
Clark, W. C. (1939). Adrenal neuroblastoma, with particular reference to metastasis to the orbit. Report of a case and notes on two other cases. Arch. Ophthal. (Chicago), 22, 575.

Cohn, M. (1894). Primäres Nebennierensarkom bei einem neunmonatlichen Kind. Berl. klin.Wschr., 31, 226. Quoted by Hutchison (1907).

Cox, R. A. (1948). Proptosis due to neuroblastoma of the adrenal cortex (Hutchinson's syndrome). Report of a case. Arch. Ophthal. (Chicago), 39,731 .

Cust, N. (1937). Neuroblastoma of the adrenal, with massive metastases and purpura. Med. J. Aust., 2, 57 .

Donnally, H. H., Rice, E. C., Jr. and Giddens, S. W. (1939). Neuroblastoma. Review and report of a case. Med. Ann. D.C. $8,208$.

Duke-Elder, Sir S. (1952). Text-book of Ophthalmology, vol. 5, p. 5618. Kimpton, London.

Fisher, Sir R. A. and Yates, F. (1957). Statistical Tables, 5th ed., pp. 2 and 45 . Oliver and Boyd, Edinburgh.

Fleming, R. A. and Davidson, J. (1924). A case of neuroblastoma (neurocytoma). Trans. med.-chir. Soc. Edinb., Session CIV (1924-1925), pp. 142-9. 
Ford, F. R. (1945). Diseases of the Nervous System in Infancy, Childhood and Adolescence, 2nd ed., p. 858. Thomas, Springfield, Illinois.

Frew, R. S. (1911). M.D. Thesis, (1910), Edinburgh University. On carcinoma originating in the suprarenal medulla in children. (See also Quart. J. Med., 4, 123.)

Gibson, T. E. (1927). The diagnosis of adrenal tumors. With classification of adrenal tumor syndromes, and report of cases. J. Urol. (Baltimore), 18, 33.

Greenthal, R. M. and Epstein, E. (1939). Adrenal neuroblastoma. Report of a case. Arch. Pediat., 56, 561 .

Greig, D. M. (1929). The cephalic metastases of suprarenal blastomata in children. Edinb. med. J., 36, 25.

Grogono, B. J. S. (1956). Neuroblastoma of the adrenal presenting with intraperitoneal haemorrhage. Brit. J. Surg., 43, 550.

Guibor, G. P. (1942). Adrenal neuroblastoma with orbital metastases. A case report with autopsy. Amer. J. Ophthal., 25, 387

Gunby, P. C. (1920). Neuroblastoma

Gupta, B. K. D. and Roy, S. (1957). Ocular metastases in HutchisonPepper syndrome. A.M.A.Arch. Ophthal. (Chicago), 57, 821.

Hansen, P. B. (1953). Sympathicoblastoma of the adrenal medulla with osseous metastases. A report of three cases, including one surviving eleven years after roentgen therapy. Acta radiol. (Stockh.), 40, 500.

Harrison, F. G., Warres, H. L. and Fust, J. A. (1950). Neuroblastoma involving the urinary tract. $J$. Urol. (Baltimore), 63,598 .

Hartung, A. and Rubert, S. R. (1935). Roentgen aspects of sympathetic neuroblastoma; with report of two cases. Radiology, 24, 607.

Henle, C-B. (1928). Roentgen findings in neuroblastoma. Amer. J. Roentgenol., $20,414$.

Holmes, G. W. and Dresser, R. (1928). Roentgenologic observations in neuroblastoma. J. Amer. med. Ass., 91, 1246.

Hutchison, R. (1907). On suprarenal sarcoma in children with metastases in the skull. Quart. J. Med., 1, 33.

Hyman, W. and Sztramski, G. A. (1955). Misdiagnosis of neuroblastoma. N.Y. St. J. Med., 55, 1344.

Karsner, H. T. (1942). Distribution of metastases of neuroblastoma of the adrenal. Trans. Ass. Amer. Phycns, 57, 209.

Kato, K. and Wachter, H. E. (1938). Adrenal sympathicoblastoma in children, with special reference to biopsy of sternal marrow and of metastatic nodule in skull. J. Pediat., 12, 449.

Klein, J. (1932). Neuroblastoma of the adrenal with multiple metastases. Amer. J. med. Sci., 184, 491.

Kuhn, H. S. (1939). Adrenal neuroblastoma and its ocular symptoms: a case report with autopsy. Amer. J. Ophthal., 22, 642.

Law, F. W. (1932). Adrenal neuroblastoma: a case with metastases causing blindness. Lancet, 2,1101 .

Leach, W. (1957). A case of neuroblastoma. Postgrad. med. J., 33,561 .

Lederer, M. (1926). Neuroblastoma of adrenal gland (Hutchinson type); report of a case. J. Cancer Res., 10, 377

Lewis, D. and Geschickter, C. F. (1934). Tumors of the sympathetic nervous system. Neuroblastoma, paraganglioma, ganglioneuroma. Arch. Surg. (Chicago), 28, 16.

Loomis, E. A. and Loomis, G. L. (1949). Adrenal sympathoblastoma (neuroblastoma). Minn. Med., 32, 606.

Lucas, P. J. (1940). Neuroblastoma with origin in the celiac ganglion. Med. Tms (N.Y.), 68, 411.

MacCarty, W. C. (1905). Berl. klin. Wschr., 42, 115, 2nd part, Festnummer f. Ewald, p. 115. Quoted by Tileston, W. and Wolbach, S. B. (1908).

Maclean, R. N. (1959). Hypercalcemia related to neuroblastoma. Arch. Pediat., 76, 64.

Mann, H. C. (1909). Primary sarcoma of the adrenal. Proc. roy. Soc. Med., 2 (Sect. Dis. Children), 160.

Moore, G. E., Sandberg, A. A. and Watne, A. L. (1959). The spread of malignant cells: a review. Univ. Mich. med. Bull., 25, 191.

Neale, A. V. (1954). In Diseases of Infancy and Childhood, ed. Sir L. Parsons, S. Barling and C. G. Parsons, 2nd ed., vol. 1, p. 481. Oxford University Press, London.
Oberkircher, O. J., Staubitz, W. J. and Parmenter, F. J. (1953). A clinical study of neuroblastoma. J. Pediat., 43, 177 .

Ogden, O. W. and Mathews, P. (1906). A case of sarcoma with secondary intra-cranial growths in a child of five. Brit. $J$. Child. Dis., 3, 394.

Onuigbo, W. I. B. (1959). Lung cancer-metastatic theory and surgical practice. J. thorac. Surg., 37, 771.

Pack, G. T., Horning, E. D. and Ariel, I. M. (1952). Neuroblastoma (sympathicoblastoma). With an analysis of 14 cases and a survey of the literature. J. Neuropath. exp. Neurol., 11, 235.

Pepper, W. (1901). A study of congenital sarcoma of the liver and suprarenal. With report of a case. Amer.J. med. Sci., 121, 287.

Pi, C. C. (1944). Adrenal neuroblastoma. Report of a case. Chin. med.J., 62A, 167.

Platt, A.H. (1911). A case of sarcoma of the supra-renal body, with secondary involvement of the vault of the skull and orbits. Ophthalmoscope (Lond.), 9, 107.

Poore, T. N. (1949). M.S. (Surgery) Thesis, University of Minnesota.

Abdominal neuroblastoma, p. 56. Abdominal neuroblastomas. Surg. Clin. N. Amer., 31, 1121.

Redman, J. L., Agerty, H. A., Barthmaier, O. F. and Fisher, H. R. (1938). Adrenal neuroblastoma. Report of a case and review of the literature. Amer. J. Dis. Child., 56, 1097.

Reiquam, C. W., Beatty, E. C., Jr. and Allen, R. P. (1956). Neuroblastomas in infancy and childhood. Ibid., 91, 588.

Riad Bey, M. (1942). Metastatic neuroblastoma of the orbit. Bull. ophthal. Soc. Egypt, 35, 81.

Rosendal, T. (1942). Two cases of sympathicoblastoma of the suprarenal gland with metastases to the cranium and the tubular bones. Acta radiol. (Stockh.), 23, 462.

Schroder, J. R. (1949). Neuroblastoma. Report of a case. Wis. med. J., 48, 1000

Seaman, W. B. and Eagleton, M. D. (1957). Radiation therapy of neuroblastoma. Radiology, 68, 1.

Shaffer, R. N. (1947). Neuroblastoma of the adrenal with orbital metastases. Report of five cases with autopsy findings. Amer. J. Ophthal., 30, 733 .

Sladden, R. A. (1953). D.M. Thesis, Oxford University. The natural history of the malignant embryonic tumours of the sympathetic nervous system, p. 85 .

Steward, J. K. (1958). In Modern Trends in Paediatrics, 2nd series, ed. A. Holzel and J. P. M. Tizard, p. 165. Butterworth, London.

Stowens, D. (1959). Pediatric Pathology, p. 347. Bailliere, Tindall and Cox, London.

Sturtevant, C. N. and Kelly, T. C. (1927). Neurocytoma of the left suprarenal gland with metastases to the liver, skull and bones. Amer. J. Dis. Child., 33, 590.

Targett, J. H. (1888). Multiple sarcomata of skull, ribs and glands. (Card specimen, Trans. path. Soc. Lond., 39, 306.

Thompson, R. M. (1942). Neuroblastoma (sympathoblastoma or neurocytoma) of the suprarenal medulla: report of three cases. Ann. intern. Med., 16, 1206.

Tidswell, F. and Sear, H. R. (1933). Neuroblastoma: Experiences at the Royal Alexandra Hospital for Children, Sydney. Aust. N.Z. J. Surg., 2, 360.

Tileston, $\dot{W}$. and Wolbach, S. B. (1908). Primary tumors of the adrenal gland in children. Report of a case of simultaneous sarcoma of the adrenal gland and of the cranium, with exophthalmos. Amer. J. med. Sci., 135, 871.

Trotter, R. F. and Winchell, W.H. (1954). Neuroblastoma. U.S. armed Forces med. J., 5, 1820.

Virchow, R. (1860). Cellular Pathology, translated by F. Chance,

pp. 158-9. Churchill, London.
Wessely (1919). Quoted by Scott, E., Oliver, M. G. and Oliver, M. H. (1933). Sympathetic tumours of the adrenal medulla; with report of four cases. Amer. J. Cancer, 17, 396.

Willis, R. A. (1952). The Spread of Tumours in the Human Body, 2nd ed., p. 104. Butterworth, London.

Wollstein, M. (1928). Neuroblastoma of the adrenal in young children. Surg. Gynec. Obstet., 46, 774. 